\title{
Uyuşturucu Bağımlıı̆ı İle Mücadelede Tedavi ve Denetimli Serbestlik Uygulamaları: Türkiye, Birleşik Devletler, Almanya ve İrlanda Örnekleri
}

Treatment and Probation Practices in Combating Drug Addiction: Turkey, United States, Germany and Ireland Samples

Sunay Fırat ' iD, Mehmet Aykut Erk (iD

\begin{abstract}
$\ddot{0 z z}$
Denetimli serbestlik kavramı ülkemizde ve dünyada hükmün verilmesi, hükümlünün sürece uygunluğunun tespit edilmesi, sürecin içeriği, süreçte rol oynayan elemanlar, sürecin içeriğindeki unsurlar ve uygulamalarda yaşanan sıkıntılar bakımından farklııklar göstermektedir. Bu farklııklardan dolayı bölgesel yönetim sistemine sahip Amerika Birleşik Devletleri ve Federal Almanya Cumhuriyeti, merkezi yönetim sistemine sahip İlanda Cumhuriyeti ve ülkemizdeki denetimli serbestlik sistemindeki "tedavi ve denetimli serbestlik tedbirleri" uygulamalar karşılaştııılmışıı. Ülkemizde özellikle uyuşturucu kullanma, bulundurma gibi suçlardan haklarında tedavi ve denetimli serbestlik tedbiri konulmuş bireylere yönelik eğitim, iyileştirme ve denetim alanlarına katkı sağlamak amacıyla, ülkelerin uygulamalarının, benzerlikleri ve farklılıkları incelenmiştir.

Anahtar sözcükler: Madde kullanım bozukluğu, denetimli serbestlik, tedavi, hükümlü.
\end{abstract}

\begin{abstract}
Probation in Turkey and in the world is different in giving a decision, determining the convict's suitability to the process, content and elements in the process, components in the content of the process and problems in the implementations. Due to these differences, treatment and probation measures in the United States and the Federal Republic of Germany, the Republic of Ireland, which has a central administration system, and the probation system in our country have been compared. In order to contribute to the fields of education, improvement and supervision for individuals who have been treated for probation and probation measures for crimes such as drug use and possession in our country, the similarities and differences of the practices of the countries have been examined. Keywords: Substance use disorder, probation process, treatment, offender.
\end{abstract}

\footnotetext{
${ }^{1}$ Çukurova Üniversitesi Bağımlıık ve Adli Bilimler Enstitüsü, Adana

Sunay Fırat, Çukurova Üniversitesi Bağımlılık ve Adli Bilimler Enstitüsü, Adana, Turkey
sunayfirat@gmail.com
}

Geliş tarihi/Submission date: 25.12 .2018 | Kabul tarihi/Accepted: 24.01.2019|Çevrimiçi yayın/Online published: 22.02.2019 
ÇAĞIMIZDA hapsetmenin, suçun tekrar etmesi (recidivism) üzerinde tek başına etkili bir yaptırım türü olmadığı bilinmektedir (Smith ve ark. 2002, Cullen ve ark. 2011). Faillerin işledikleri iddia edilen çeşitli suçlardan dolayı hapsedilmelerine yönelik mevcut alternatiflerden biri denetimli serbestliktir. Denetimli serbestlik, "Mahkemece belirtilen koşullar ve süre içinde, denetim ve denetleme planı doğrultusunda şüpheli, sanık veya hükümlünün toplumla bütünleşmesi açısından ihtiyaç duyduğu her türlü hizmet, program ve kaynakların sağlandığı toplum temelli bir uygulamayı" ifade etmektedir. Diğer bir ifadeyle denetimli serbestlik, hükümlülerin suç işlemesine neden olan davranışlarının düzeltilerek, tekrar suç işlemelerinin önlenmesi, ceza infaz kurumundan salıverilen hükümlülerin takip edilmesi, madde bağımlılarının rehabilitasyonu, mağdurların uğradıkları zararın giderilmesi ve bu yolla toplumun korunmasıdır (Resmi Gazete 2005).

Denetimli serbestlik sisteminin denetim ve (bireylere/hükümlüye ya da çeşitli suçlardan mahkemelerce haklarında denetimli serbestlik, tedavi ve denetimli serbestlik gibi tedbirler konulmuş bireylere) yardım etmek gibi iki temel görevi bulunmaktadır. Faillerin cezalandırılması, Hükümlülerin iyileştirilmesi, topluma ve/veya mağdura verilen zararın onarılması ve toplumun düzenini bozan ve yasalara aykırı eylemlerden korunması denetimli serbestlik sisteminin uluslararası kabul gören temel amaçları olarak kabul edilmektedir (Asthal 2006).

\section{Denetimli Serbestlik Sistemi}

Denetimli serbestlik gibi hapis cezası içermeyen hükümler; bireylerde cezaevi yaşantısının yarattığı fiziksel ve psikolojik olumsuzlukları ortadan kaldırmakta, cezaevi yaşantısına alternatif olarak hükümlülerin infaz süresi boyunca eğitsel ve sağaltıcı programlara da katılımlarını sağlamaktadır (Tongzhi 2008). Denetimli serbestlik sistemi hükümlüye; kendini mağdurun yerine koyabilmesi, oluşan zararı onarabilmesi, içinde yaşamını sürdürdüğü topluma ve ülkeye yapabileceği çeşitli katkılar (vatandaşlık görevleri, çevresindeki gençleri uyuşturucunun zararları hakkında bilinçlendirmesine kadar farklı konuların çalışılması yoluyla) sağlama şansı tanımaktadır. Ayrıca, denetimli serbestlik uygulamaları kapsamında öfke kontrol becerisi ve stres yönetimi gibi çeşitli konularda bireylerarası farklılıklar göz önünde tutularak bireylerin ihtiyaçları doğrultusunda rehberlik faaliyetleri de yürütülebilmektedir (Tuncer ve Duru 2011).

Tedavi ve denetimli serbestlik kararı birçok adli olguya verilebilen, aynı zamanda Türkiye Cumhuriyet Sağlık Bakanlığı, Sağlık Hizmetleri Genel Müdürlüğünün 2006/19 ve 2009/82 sayılı Genelgeleri ile düzenlenmiştir. Denetimli Serbestlik Tedbirleri Uygulanan Kişilerin Tedavilerine İlişkin Genelgesi uyarınca; Türk Ceza Kanunun 191. Maddesinde yapılan değişiklikler de dikkate alınarak mevcut genelgelerin günümüz şartlarına göre yeniden düzenlenmesine ve denetimli serbestlik tedavi hizmetleri kapsamında madde bağımlılığı tedavi merkezlerinde verilecek ileri tedavi hizmetlerinin standart bir şekilde sunulmasına ihtiyaç duyulmaktadır. Böylece sağlık kuruluşlarında denetimli serbestlik tedavi uygulamaları her ilde belirlenen kamu kurum ve kuruluşları bünyesinde yer alan yataklı sağlık kuruluşlarında verilmekte, denetimli serbestlik kapsamında verilecek tedavi hizmeti ihtiyacını İl Sağlık Müdürlüğü değerlendirmekte ve tedavi hizmetini verecek sağlık kurumunu belirlemektedir. Dolayısıyla toplum sağlığ1nın korunması ve iyileştirilmesi amacıyla uyarıcı ve uyuşturucu madde kullanan veya bağımlısı olan bireylerin topluma kazandırılmasının hedeflendiği belirtilmiştir (Akbaş 
ve Mutlu 2016).

Denetimli serbestlik kavramı ülkemizde ve dünyada hükmün verilmesi, hükümlünün sürece uygunluğunun tespit edilmesi, sürecin içeriği, süreçte rol oynayan elemanlar, sürecin içeriğindeki unsurlar ve uygulamalarda yaşanan sıkıntılar bakımından farklılıklar göstermektedir (Mutz 2009, Tuncer ve Duru 2011, Dessecker 2012, Décarpes ve Durnescu 2014, Clarke ve Eustace 2016). Bu farklılıklardan dolayı bölgesel yönetim sistemine sahip Amerika Birleşik Devletleri (ABD) ve Federal Almanya Cumhuriyeti, merkezi yönetim sistemine sahip İrlanda Cumhuriyeti ve ülkemizdeki Denetimli Serbestlik sistemindeki "tedavi ve denetimli serbestlik tedbirleri” uygulamalar karşılaştırılacak ve ülkemizde özellikle uyuşturucu kullanma, bulundurma gibi suçlardan haklarında tedavi ve denetimli serbestlik tedbiri konulmuş bireylere yönelik eğitim, iyileştirme ve denetim alanlarına katkı sağlamak amacıyla, ülkelerin uygulamalarının, benzerlikleri ve farklılıkları literatür temelli incelenecektir.

Bu çalışmada ABD ve Almanya'ya bölgesel yönetim şekillerince özelleşen ceza adalet sistemi anlayışları bakımından yer verilmişken, İrlanda ise alkol bağımlılı̆̆ından kaynaklı suç oranlarının yüksek olduğu bir ülke (Martyn 2012) olmasına karşın bu problemin çözümüne yönelik etkili olabileceği düşünülen denetimli serbestlik yaklaşımlarının incelenmesi sebebiyle dahil edilmiştir. Yapılan karşılaştırmalı değerlendirmeler sonucunda ülkemizdeki "Mahkemece belirtilen koşullar ve süre içinde, denetim ve denetleme planı doğrultusunda şüpheli, sanık veya hükümlünün toplumla bütünleşmesi açısından ihtiyaç duyduğu her türlü hizmet, program ve kaynakların sağlandığı toplum temelli denetimli serbestlik sistemi uygulamasına” yasalar, mevzuatlar ve yönergeler çerçevesinde katkı sağlayabilmek için birtakım önerilerde bulunulacaktır.

\section{ABD'de Denetimli Serbestlik Sistemi Uygulamaları}

ABD'de denetimli serbestlik uygulamaları ceza adalet sistemine bazen federatif veya eyalet düzeyinde bazen de yerel yönetim düzeyinde yüzlerce organizasyon ve yapı tarafindan hizmet vermektedir. Dolayısıyla ABD'deki denetimli serbestlik sistemi, eyaletler düzeyinde ortak bir yaptırımı ve standart uygulamaları olmayan ve yerel yönetimlere bağlı bir şekilde ülke geneline uygulanmaktadır (Burrell 2010). Ancak sistemin ortak amacı yeniden suça karışma (recidivism) olgusunun önüne geçebilmektir. Bunun için gerçekleştirilen bazı uygulamalar (süpervizyon, infaz, tedavi ve rehabilitasyon programları, elektronik izleme vb.) kaynağını mahkeme kararlarından temel alırken diğer bazı uygulamalar da denetim serbestlik personelleri tarafından mağdur desteği, (klinikler) kaynağını eyaletlerin yasalarından temel almaktadır.. Daha genel bir bakış açısıyla denetimli serbestlik sistemi, topluma - okullarda veya diğer önemli toplum merkezlerinde önleyici hizmetler yoluyla- hizmet etmektedir (Décarpes ve Durnescu 2014). ABD'de de hemen hemen her adli yargilama sürecinde mahkeme öncesi; adli olguyu multidisipliner olarak değerlendiren raporlar ve sosyal inceleme raporları vb. gibi adli olgu hakkında karar verme/değerlendirme destekleri, hükümlülerin topluma entegrasyonunun sağlanabilmesi için denetimli serbestlik uzmanları tarafından denetimli serbestlik hükümlülerine verilen süpervizyonları ve yine hükümlülerin kriminojenik ihtiyaçlarına yönelik rehabilitasyon desteği gibi temel denetimli serbestlik faaliyetleri bulunmaktadır (Décarpes ve Durnescu 2014).

ABD'de uygulanan denetimli serbestlik sistemi içerisinde birey, kendisine denetimli serbestlik süresince danı̧̧manlık yapacak denetimli serbestlik uzmanının olduğu eyalette 
bulunan "Yetişkin Denetimli Serbestlik Departmanı'na" başvurmaktadır. Adı geçen bölüme başvuruda bulunan birey başlangıçta haftada bir kere danı̧̧manı ile görüşmeye gitmekle yükümlüdür. Birey, denetimli serbestlik hükümlülüklerini yasalarda belirtildiği gibi uygun bir biçimde yerine getirmeye devam ettikçe danışmanı veya diğer uzmanlar ile görüşme sayıları ve sıklığı bireyin programı çerçevesinde azaltılmaya çalışılmaktadır (Décarpes ve Durnescu 2014).

Birey, uyuşturucu madde bulundurursa ve/veya kullanırsa ya da uyuşturucu maddenin etkisindeyken suç içeren herhangi bir davranışta bulunursa kolluk kuvvetleri tarafından gözaltına alınmakta, daha sonra savcılık makamı tarafindan soruşturması başlatılmakta ve bu süre zarfinda birey eğer gerek duyulursa bir gece cezaevinde tutulabilmektedir. Bu bireyler için sonraki süreçlerde denetimli serbestlik veya güvenlik tedbiri durumlarında rutin olarak yapilan adli toksikolojik analizlerin (uyuşturucu madde testleri) uygulanması mevzuata göre zorunlu iken, başka bir suç içeren herhangi bir suç davranışında bulunduğu zaman toksikolojik analizler zorunlu olmayabilmektedir. "ABD Hüküm Yönergesine” göre mahkeme tarafından, denetimli serbestlik hükümlüsü için, oluşturulmuş olan ruh sağlığı programlarına katılmasını uygun gören hükümler doğrultusunda psikolojik ve psikiyatrik tedaviye ihtiyacı olduğuna dair bir kanaat gelişirse, ilgili tedavi kuruluşlarına yönlendirmelerinin yapılması da sağlanmaktadır.

Yasa ve yasal merciler, bireylerin uyuşturucu madde kullanımında, ateşli silah bulundurma veya adli toksikolojik analizlerin yapılmasını (uyuşturucu madde testi) reddetmesi gibi durumlarda denetimli serbestlik tedbiri kararının iptalini isteyebilmekte ve hükümlüler cezaevine gönderilmektedirler. (18 U.S. Code $§ 3563$ 1987).

“Tedavi ve Denetimli Serbestlik Tedbiri” alan bütün hükümlülerin uyması gereken temel kurallar şunlardır:

Hükümlü:

- Herhangi bir eyalette ya da yerel küçük yerleşim yerlerinde suç içeren herhangi bir davranışta bulunmamalıdır,

- Uyuşturucu madde bulundurmamalı ve/veya kullanmamalıdır,

- Denetimli Serbestlik hükümlülerine hüküm verildikten sonra 15 gün içerisinde ilk toksikolojik analizlerini (uyuşturucu madde testi) ve en az iki periyodik toksikolojik analizlerini de (uyuşturucu madde testi) yaptırmak zorundadırlar. (Williams v. Hunter 1957)

Bazı durumlarda, mahkeme kararı ile, alkol dahil olmak üzere satışı yasal olan bağımlılık yapıcı maddelerin de "tedavi ve denetimli serbestlik tedbiri "kararı verilen hükümlüler tarafindan kullanımı yasaklanabilmektedir, (United States v. Schave 1999) ancak bu durumun gerçekleşebilmesi için hükümlünün suçuna ilişkin somut verilere gereksinim duyulmaktadır (United States v. Stoural 1993). Eğer bireyin; alkol ve/veya madde bağımlılığından kaynaklı herhangi bir suçu bulunmamasına rağmen, yüksek dozda uyuşturucu ya da alkol kullanımı nedeniyle ilgili mahkeme faile ayaktan tedavi hükmü verebilmektedir (United States v. Carter 1998). Mahkeme öncesi adli olguyu değerlendirme raporları, adli olgu hakkında karar verme gibi değerlendirme veya sosyal inceleme raporlarında hükümlünün madde kullanımında düşük riskli grupta olduğu belirlenirse mahkeme yasalarla belirlenmiş rutin adli toksikolojik analizlerin yapılması hükmünden de vazgeçebilmektedir (18 U.S. Code $§ 3563$ 1987). Bireyin kullanıcı olmasına rağmen, işlemiş olduğu suçun uyuşturucu madde ile bağlantılı olmadiğına karar verilirse mahkeme, failin (somut delillerle suçu kesinleşmişse "sanık" olacaktır.) 
zorunlu adli toksikolojik analizlerinin yapılmasına hükmetmeyebilir. Örneğin; mahkeme, bireyin, bir hafta sonu boyunca 12 şişe bira tüketiminin alkol kötüye kullanımı olmadığı yönünde karar verebilmektedir (United States v. Stephenson 1991).

Mahkeme tarafindan hükmedilen "tedavi ve denetimli serbestlik tedbiri” kararından sonra hükümlünün sosyal uyum süreci onu denetleyen denetimli serbestlik personeli/uzmanı ile devam etmektedir. Denetimli serbestlik uzmanlarının profesyonel yaklaşımları suçun yeniden işlenmesinin önlenmesinde ve suçlunun yeniden topluma kazandırılmasında önem arz etmektedir. Yapılan çalışmalarda denetimli serbestlik uzmanı ile hükümlü arasındaki ilişkide hükümlünün davranış değişikliğine odaklanan personelin/uzmanların, hükümlünün sadece haklarıla/sorumluluklarıla ilgilenen personele/uzmana göre suçun yeniden işlenmesinin önlenmesinde daha fazla katkıda bulunduğu anlaşılmıştır (Décarpes ve Durnescu 2014, Miller 2015). 1990’ların başından itibaren ABD'de denetimli serbestlik personeli/uzmanı ve hükümlü etkileşimlerinde risk değerlendirmesi kavramı öne çıkmaktadır. Risk değerlendirme kavramı, bireyin davranışlarını değiştirerek çevresindekiler ile olumlu ilişkiler kurabilmesine yönelik girişimlerde bulunan "sosyal-öğrenme teorisi" ve "bilişsel-davranışçı" yaklaşımlarından ilham alarak gerçekleştirilmektedir (Alexander ve ark. 2014). Sosyal öğrenme teorisi, insanların sadece kendi deneyimlerinden değil aynı zamanda başka insanların ortaya koydukları davranışları, davranışların sonuçları veya televizyon, sinema vb. gibi görsel medya unsurlarından gözlemledikleri deneyimleri inceleyerek ve sonuçlar hakkında çıkarımlarda bulunarak olumlu davranış geliştirme becerileri kazandırmayı dolayısıyla öğrenmeyi öne çıkarmaktadır. Ayrıca sosyal öğrenme teorisi, bireylerin yaşadıkları içsel ödüllenmelerin (onur, haz, iyi-oluş hali vb.) en az başkaları tarafindan verilen ödüller kadar önemli olduğunu da vurgulamaktadır (Alexander ve ark. 2014).

ABD'de de, denetimli serbestlik hizmetleri kapsamında görev alan personel ve uzmanların, hükümlü bireylerde gerçekleşmesi beklenen davranış değişikliğine ulaşabilmesi için empatik yaklaşım ögelerine uygun ilişkiler kurması beklenmektedir (Alexander ve ark. 2014). ABD'de bu empatik, problem çözme becerilerine yönelik ve toplumcu yaklaşımların bir bütünü olan uygulamaların kullanımı Trotter'ın (1996) araştırmalarına göre yeniden suça yönelme üzerinde olumlu etkilere sahiptir.

Sonuç olarak ABD'de denetimli serbestlik süreci, her ne kadar eyaletler bazındaki işleyiş anlamında değişiklikler gösterse de mahkemeler tarafindan haklarında "tedavi ve denetimli serbestlik tedbiri” kararı verilmiş hükümlülerin tedavi, rehabilitasyon ve sosyal uyumları bakımından belirli standartlara sahiptir. Bununla birlikte eyaletin denetimli serbestlik ofisleri yetersiz kaldığında hükümlüler özel denetimli serbestlik ofislerine de yönlendirilebilmektedir. ABD'deki yerel sistemlerin merkezi standartlara sahip olduğu söylenebilmektedir.

\section{Almanya'da Denetimli Serbestlik Sistemi Uygulamalan}

Almanya Federal Cumhuriyeti'nde denetimli serbestlik uygulamaları ise ABD'de olduğu gibi ceza adalet sisteminin içinde ve kurumun bir parçası olan, denetimli serbestlik hükümlülerinin toplum içerisinde gözetim, denetim, takip ve iyileştirilmesini kapsayan faaliyet ve uygulamaların yer aldığı sosyal servislerde tam anlamıyla bir bütünlükten söz edilememektedir (Mutz 2008, Dessecker 2012).

Almanya'daki denetimli serbestlik tedbiri kararı Alman Ceza Kanunu'nun 56. maddesi (StGB) ve Alman Çocuk Mahkemeleri Yasası'nın 21. maddesine (JGG) göre 
alınmaktadır ( $\$ 56$ German Criminal Code StGB 2013, §21 German Youth Courts Law JGG 2017). Denetimli serbestlik kararı, "Lander"e (Eyaletlere) bağlı hakimler tarafindan 2 yıldan 5 yıla kadar olan hapis cezaları hükümleri yerine verilebilmektedir. "Denetimli serbestlik tedbiri" kararını veren mahkemeler tarafindan, bireylere/sanıklara verilen "denetimli serbestlik tedbiri” kararları verilen hükümlülerin, bu yasal sürece uyum yapıp yapmadıklarına göre hüküm süreleri dolmadan önce minimum ceza süresine indirilebilmekte veya maksimum ceza süresine çıkarılabilmektedir. Benzer olarak, "denetimli serbestlik tedbiri" kararını veren mahkemeler tarafından suça sürüklenen çocuk veya ergenlerde ise "denetimli serbestlik tedbiri" kararı 2 ya da 3 yil olarak verilmekte ve "denetimli serbestlik tedbiri" kararları verilen suça sürüklenen çocuk veya ergenlerin, bu yasal sürece uyum yapıp yapmadıklarına göre hüküm süreleri dolmadan önce süre 1 yıla kadar indirilebilmekte veya 4 yıla kadar çıkarılabilmektedir ( $\$ 56$ German Criminal Code StGB 2013).

Birçok ülkenin denetimli serbestlik modelinde olduğu gibi Almanya'daki denetimli serbestlik modellerinde de denetimli serbestlik hükümlüleri, belirli yerlere gidememek ya da mahkeme tarafından belirlenmiş alanlardan çıkamamak, ücretsiz toplumsal hizmetlerde bulunmak, mahkeme tarafindan belirlenmiş miktarda para ödemek vb. hükümleri yerine getirmekle yükümlüdür. Denetimli serbestlik tedbiri kararları verilen suça sürüklenen çocuk veya ergenlerin için ebeveyninin ya da bakmakla yükümlü olanların veya yasal velisinin/vasisinin rızasıyla, ilgili mahkeme, madde kullanım bozukluğu tedavisi ve/veya ruhsal destek kararı verebilmektedir. Ĕger denetimli serbestlik tedbiri kararı verilen suça sürüklenen çocuk veya ergenlerin yaşı 16 yaşından büyük ise bu karar sadece çocuğun/ergenin rızası alınarak verilebilmektedir (\$21 German Youth Courts Law 2017).

Mahkeme tarafindan yasalar kapsamında verilen kararlardan sonra çocuk/ergen/yetişkin bireyler bulundukları eyaletin denetimli serbestlik bürosuyla irtibata geçmektedirler. Eyalet yasalarına göre; örneğin; Aşağı Saksonya eyaletinde, denetimli serbestlik tedbiri kararları verilen bireyler, mahkeme kararlarını takip eden 14 gün içerisinde bulundukları eyaletteki denetimli serbestlik uzmanı veya personeli ile ilk irtibatı kurmak zorundadırlar (Mutz 2008, Dessecker 2012). Ayrıca ilgili mahkeme tarafından, eğer hükümlünün birtakım davranış bozuklukları olduğuna yönelik veriler tespit edilirse, denetimli serbestlik süresince hükümlünün aynı zamanda ruhsal bozukluğunun incelenmesi, değerlendirilmesi ve ruh ve sinir hastalıkları hastanesine yatış kararları da verebilmektedir. Yine ilgili mahkeme tarafından hükümlünün madde kulla$\mathrm{nım} /$ madde bağımlılığı gibi bir bozukluğu olabileceği şüphesinin var olduğu durumlarda, hükümlünün ilgili hastanelerin kliniklerine yatırılması ve madde bağımlılığı tedavisinin başlatılması kararını da verebilmektedir ( $\$ 67 \mathrm{~b}$ German Criminal Code StGB 2013).

Almanya'da, kişilerin üzerinde bulundurduğu uyuşturucu miktarı, kişinin alacağı ceza oranını da etkilemektedir. Bu durum yine eyaletlere göre farklılık göstermektedir. Berlin eyaletinde 15 grama kadar esrar bulundurmak/kullanmak cezai bir durum teşkil etmezken, Bremen eyaletinde bu sınır 6 gramdır (Bireysel uyuşturucu bulundurmaya ilişkin $\S \S 29,31 \mathrm{a}$ Law on Traffic in Narcotics BtMG 2018). Kişilerin üzerinde eğer bu oranların altında madde bulunduğu tespit edilirse aşırı kaçmamak koşuluyla mahkemeler tarafından küçük cezalar verilebilmektedir. Şayet üzerinde normal sınırın altında madde bulunduran kişilerin suç geçmişi varsa ve haklarında daha önceden birden fazla 
adli karar verilme öyküsü varsa, hâkim bu kişilerin iyileştirme/rehabilitasyon programlarına zorunlu katılım kararı verebilmektedir (Loschnig-Gspandl ve Kilchling 1997).

Denetimli serbestlik tedbiri kararları verilen suça sürüklenen çocuk veya ergenlerin bu süreçte iken madde kullandıkları tespit edildiği durumlarda, madde kullanımına bağlı tehlike yaratacak ya da suça yönelimini arttıracak bir durum yoksa denetimli serbestlik uzmanları/personelleri çocuk veya ergenlerdeki bu durumu ilgili yargıca bildirmek zorunda değildir, ancak bu kapsamda onları gözetim altında tutmak ve denetimlerini yapmak zorundadır. Ancak çocuk veya ergenlerdeki madde kullanımına bağlı tehlike yaratacak ya da suça yönelimi ve yeni suçlar işleme durumları gündeme gelirse hükümlünün bazı bilgilerinin gizliliği ilkesi kapsamında denetimli serbestlik uzmanının bu gelişmeyi polise (kolluk kuvvetlerine) değil yargıca bildirme sorumluluğu bulunmaktadır (Loschnig-Gspandl ve Kilchling 1997, Ceza ve Tevkif Evleri Genel Müdürlüğü 2009).

Almanya yasalarında uyuşturucu bağımlısı bireyler için hapis cezasını ertelemeye yönelik başka bir uygulama daha bulunmaktadır ( $\$ 35,36$ Law on Traffic in Narcotics BtMG 2018). Uyuşturucu bağımlısı olan bireylere ilgili mahkeme tarafından iki yıldan daha uzun süre olmayan hapis cezası hükmüne varıldıysa, bu bireyler cezaevine gönderilmemekte, bağımlılık tedavisi yapılan bir enstitüde tedavi ve rehabilitasyonun sağlanması koşulu ile hapis cezası kararı ertelenebilmektedir. Bireyin bağımlılık tedavisi yapıldığ1 enstitüde, tedavi için geçirdiği süre verilen ceza süresinin 2/3'üne kadar sayılabilmektedir. Genel olarak, hükümlüler madde bağımlılığ1 tedavi sürecini uyumlu bir şekilde geçirip, tedavi süreçlerine olumlu katkıda bulunduklarında, geri kalan ceza sürelerini denetimli serbestlik sürecinde geçirmektedirler (Mutz 2008, Dessecker 2012).

Almanya yasalarına göre, ceza adalet sistemi içerisinde sosyal pedagoglar ya da sosyal çalışmacılar yaptıkları işlevlerin niteliklerine göre farklı uzmanlık tanımlarına sahiptirler (Mutz 2008, Dessecker 2012). Denetimli serbestlik uzmanlar1/personelleri hükümlülere süreçte rehberlik yapmak ve süpervizyon vererek rol oynarken, sosyal çalışmacılar ise bireyin bu süreçten önceki sosyal yaşamını ve kişiliği incelemekle görevlidirler. Aynı zamanda sosyal pedagoglar ya da sosyal çalışmacılar "mahkeme asistanı" unvanını almakta ve mahkemeye görüş bildirmek ve hükümlülerin rehabilitasyonu gibi farklı iş tanımlarına da sahiptirler (Mutz 2008, Dessecker 2012).

$\mathrm{Bu}$ süreçte sosyal pedagog/sosyal çalışmacı birçok görev üstlenmektedirler. Hükümlü ile süpervizyon çalışmaları, bu çalışmaları gerçekleştirirken aynı zamanda verilecek desteğin yoğunluğu, hükümlünün sosyal çevresinin özellikleri, Denetimli serbestlik tedbiri kararını olumlu/olumsuz etkileyebilecek önemli verilerin değerlendirilmesi, taranması, rapor haline getirilmesi ve soruşturma-kovuşturma sürecinde gelişebilecek diğer görevler olmak üzere ceza adalet sistemi içerisinde çok yönlü görev almaktadırlar (Mutz 2008, Dessecker 2012). Bununla birlikte suçun doğası ve tekrarının önlenmesi çok önemli olduğundan uzmanlar/personeller tarafından bireylerin kişilik özellikleri, mahkeme öncesi, mahkeme sürecinde ve mahkeme-sonrasında değerlendirmeleri yapilmakta ve bireyler hakkında raporlar düzenlenmektedir (Mutz 2008, Dessecker 2012). Savcı, soruşturma evresinde, bireyler hakkında mahkeme öncesi hazırlanan raporu da dikkate almakta, mahkeme asistanından ilgili şüpheli hakkında yaşam koşulları, madde bağımlılığı öyküsünün bulunup bulunmadığı, borçları, yaşamını sürdürecek bir işinin olup olmadığı vb. verileri talep edebilmekte, mahkeme asistanları da sanıklarla amaç odaklı görüşmeler yapabilmektedirler. Ĕger gerek duyulursa mahkeme asistanları sanığın ailesi, yakınları ve sosyal çevresi ile de görüşmeler gerçekleştirebilmektedirler. Gö- 
rüşmeler sonunda bireyler hakkında raporlar hazırlanmakta ve adli süreci kolaylaştırması bakımından bu görüşme raporları önem arz etmektedir (Mutz 2008, Dessecker 2012). Benzer olarak, Federal Adalet Yüksek Mahkemesi (Bundesgerichshof) hükümlünün kişiliğinin değerlendirilmesinin suçun koşullarının incelenmesi kadar önemli olduğunu vurgulamaktadır (Mutz 2008, Dessecker 2012).

Almanya'daki denetimli serbestlik uygulamalarından biri de "arabuluculuk" hizme-

tidir. Eğer savcı, işlendiği iddia edilen suçun, mağdur ile fail/hükümlü arasında bir uzlaşmanın mümkün olabileceğine karar verirse, taraflara arabuluculuk yapması için mahkeme asistanlarına görev verebilmektedir. Çünkü bu süreçte mağdur ile fail arasındaki uzlaşmacı tutum, ceza adalet sisteminde savcılık soruşturmasının geri çekilmesine kadar varabilen sonuçlara yol açmaktadır. Arabuluculuk uygulamalarının amacı, yasal yollarla barışı sağlamak ve mağdur ile faili uzlaştırmaktır. Bu sayede failin kişisel taahhüt sağlaması, mağdur ile arasındaki çatışmaları çözmesine yardım edecektir. Sanıldığından farklı olarak failin/hükümlünün, mağdurun duygularıyla ve işlenen suçun fiziksel, maddi ve psikolojik sonuçlarıyla direkt yüzleştirilmesi, hükümlünün tutum ve davranışlarında değişimlere neden olabilmektedir. Failin, mağdurla yüzleşmesi ve olumsuz sonuçların giderilmesine yönelik girişimlerde bulunulması, failde uzun süreli olumlu davranış değişiklikleri ile sonuçlanabilmektedir (Ceza ve Tevkif Evleri Genel Müdürlüğü 2009). Almanya'da arabuluculuk uygulamaları aynı zamanda ceza infaz kurumlarında eğitim olarak da verilmektedir. Daha çok genç hükümlülerin rağbet ettiği bu eğitim sonucunda hükümlüler hakkında bir ceza infaz raporu oluşturulmaktadır. Psikologlar/psikolojik danışmanlar, sosyal çalışmacılar, öğretmenler ve infaz koruma memurları genci değerlendirerek kapsamlı bir rapor oluşmasına katkı sağlamaktadırlar. Bu eğitimin sonucunda hükümlü de "sivil arabuluculuk" yapabilmektedirler (Ceza ve Tevkif Evleri Genel Müdürlüğü 2009).

Faile/sanığa işlediği iddia edilen suç hakkında mahkeme tarafından herhangi bir cezaya hükmedilmeden önce "mahkeme asistanları" tarafindan hazırlanan "Hüküm öncesi raporlarda" ise failin yalnızca kişiliği ve sosyal çevresi hakkında bilgiler alınmamakta aynı zamanda kararın seyrini değiştirebilecek psiko-sosyal tanılar (ruhsal tanılar?) ve durum analizleri de yapılmaktadır. Genel olarak hazırlanan bu raporlar, faile/sanığa işlediği iddia edilen suç hakkında mahkeme tarafından verilen cezai yaptırımlardan kaynaklanabilecek olumsuzlukları da en aza indirmeye çalışmaktadırlar (Mutz 2008, Dessecker 2012). Anlaşılacağı üzere Almanya'daki "tedavi ve denetimli serbestlik tedbiri” uygulamaları sadece ceza adalet sisteminin içinde yapılması gerekenler listesi gibi ağır değil aynı zamanda hükümlülere diğer gelişmiş ülkelerdeki sosyal uyum standartlarının da üstünde bir sosyal yaklaşıma sahiptir. Örnek olarak Kuzey-Ren Vestfalya eyaletinde; denetimli serbestlik hükümlülerinin insan ilişkilerinin yeniden düzenlenmesi, psiko-sosyal danışmanlık, bağımlılara yardım ve tedavi hizmetleri, iş hayatına yeniden adaptasyon gibi birçok ilke, temel sorumluluklar listesindedir (Mutz 2009, Dessecker 2012).

\section{İrlanda'da Denetimli Serbestlik Sistemi Uygulamaları}

İrlanda'da denetimli serbestlik uygulamaları genellikle ilgili "Sivil Toplum Kuruluşları" (STK) tarafından yürütülmektedir. "Denetimli serbestlik tedbiri” kararı verilen hükümlülerin karardan sonra adli toksikolojik değerlendirmelerinin yapılması, hükümlülerin psiko-sosyal yönden değerlendirilmeleri sonucunda denetimli serbestlik tedbir kararına 
uygun olup olmadıklarının belirlenmesi ve denetimli serbestlik sürecindeki geri kalan birçok uygulama STK'larca yerine getirilmektedir.

Eğer bir birey cezai yaptırımı olan bir sebepten ötürü herhangi bir suçtan dolayı suçlu bulunursa ya da suçunu itiraf ederse, yargıç ceza adalet sistemi yargılama sürecinde herhangi bir cezaya hükmetmeden önce uzmanlardan "denetimli serbestlik raporu" isteyebilmektedir.

İrlanda'da denetimli serbestlik uygulamalarında bireyleri değerlendirdikleri iki rapor türü bulunmaktadır:

- Hüküm-öncesi raporu

- Hapis cezası yerine "denetimli serbestlik tedbiri” hükmünü verebilmesi için uygun koşulların sağlanıp sağlanmadığını değerlendiren kamu hizmeti raporu.

İlgili mahkemenin yargıcı bireyleri değerlendirdikleri raporlardan birinin veya her ikisinin de hazırlanmasını isteyebilmektedir. Yargıçlar istedikleri raporların hazırlanabilmesi ve mahkemeye sunulabilmesi için duruşmayı bir sonraki oturuma erteleyebilmektedir. Mahkeme, genellikle sözü edilen değerlendirme raporlarının hazırlanabilmesi için yetişkin bireyler için 8 hafta, çocuk ve ergen bireyler için ise 4 hafta süre verebilmektedir(The Probation Service 2016).

"Denetimli serbestlik tedbiri" kararı verilen hükümlülerin özellikle uyuşturucu madde kullanımı ve bağımlılı̆̆ı tedavisi ve rehabilitasyonu birlikte yürütüldüğü zaman denetimli serbestlik süreci; hükümlünün süreç-öncesi değerlendirilmesi, uygun tedavi ve rehabilitasyon kurumlarına yönlendirilmesi/sevk, periyodik olarak değerlendirilmeleri, bireysel bakım planlarının hazırlanması, kısaca olgunun yönetimi, tedavi süreci ve iyileşme süreci yönetimi aşamalarına sahiptir. Bu aşamalardan önce ilgili mahkemenin hâkimi bireye "denetimli serbestlik tedbiri" kararı verebilmekte ve denetimli serbestlik ofisleri ve STK'larca aşamalar uygulamaya konulmaktadır. "Denetimli serbestlik tedbir" kararı etkili bir süreç-öncesi planlamanın yapılabilmesi diğer aşamalar için de etkili olabilmektedir. Özellikle alkol kötüye kullanımı olan hükümlülerde alkol düzeyi taramasının yapılması ve tespiti mümkün oldukça çabuk yapılabilmektedir (Martyn 2012, Clarke ve Eustace 2016).

"Denetimli serbestlik tedbiri” kararı verilen hükümlülerin gereksinimleri gözetilerek denetimli serbestlik sürecindeki mevcut uygulamalardan ve rehabilitasyon hizmetlerinden yararlanabilmesi ve gerçekleştireceği kamu hizmetlerine yönlendirmeler yapılmaktadır. Bu aşamada hükümlünün ilgili organizasyonlara ve kuruluşlara bizzat başvurmasi desteklenmektedir (Clarke ve Eustace 2016, The Probation Service 2017).

Denetimli serbestlik sürecinde hükümlünün, değerlendirildiği, bağımlılıklarının neler olduğunun ve sonuçlarının incelendiği ve buna yönelik ihtiyaçların araştırıldığı, tedavi ve rehabilitasyon sürecine yönelik motivasyonun incelendiği aynı zamanda suçun yeniden meydana gelmesi olgusuna neden olduğu düşünülen risk faktörlerinin yordanmaktadır. Etkili bir değerlendirmenin yapılabilmesi için, birey merkezli değerlendirmenin başlatılması, denetimli serbestlik ofisine gelen hükümlünün zaman kaybetmeden değerlendirilmesi, bağımlılık şiddetinin ve psikolojik fonksiyonlarının uygun bir biçimde araştırılması gerçekleştirilmektedir (Geiran 2011, Clarke ve Eustace 2016). Hükümlünün değerlendirme süreci denetimli serbestlik personelleriyle hükümlünün birebir iletişim kurduğu önemli anlardan biridir. Bu yüzden iletişimin sağlıklı kurulması bireyin davranışlarına sirayet edebileceğinden ötürü, sağlam örüntülü bir iletişim modeli denetimli serbestlik ofisi, STK ve hükümlü arasındaki işlerliği ciddi ölçüde gereklidir (Clar- 
ke ve Eustace 2016). Değerlendirme sonucunda hükümlünün tedavi ve rehabilitasyon sürecinde mevcut programlara uygunluğu tespit edilmektedir. Ruhsal değerlendirme sonucunda, hükümlülerin önemli derecede psikiyatrik bozukluğu olduğu belirlendiği taktirde hükümlüler STK'lar tarafından gerçekleştirilen rehabilitasyon uygulamalarına yönlendirilmemektedir. Böyle durumlarda uzmanlar tarafindan hazırlanan ve hükümlünün değerlendirilme sonuçlarının yer aldığı bir rapor ilgili mahkemeye tekrar sunulmakta ve hükümlü hakkında daha önceden ilgili mahkeme tarafından hükmedilen karara, bireyin psikiyatrik bozukluklarının tedavisinin de yapılmasını içerecek biçimde önceki kararın yeniden düzenlenmesi ve yeni bir karara hükmedilmesi talep edilmektedir (Geiran 2011, Clarke ve Eustace 2016).

İrlanda ceza adalet sisteminde "denetimli serbestlik tedbiri" sürecinde hükümlüler standartlaştırılmış görüşme ve inceleme yöntemleri ile değerlendirilmelerine rağmen ilgili her STK'nın kendine ait özelleştirilmiş değerlendirme envanterlerini de bulunmakta ve bu kuruluşlar gerektiği durumlarda onları da kullanabilmektedirler. Denetimli serbestlik sürecinde değerlendirme araçları gibi değerlendirmeyi yapan uzmanlar da çeşitlilik gösterebilmektedir. Örneğin Cuan Mhuire'de standart denetimli serbestlik personellerinden/uzmanlarından farklı olarak "bağımlılık danışmanları" ve "uzman hemşireler" tarafindan hükümlülerin değerlendirmeleri gerçekleştirilmektedir (Geiran 2011, Clarke ve Eustace 2016).

İrlanda'da 2016 yılında yetişkinlerin işledikleri suçların türlerinin incelendiği bir çalı̧̧mada, uyuşturucu madde ile ilişkili olarak işlenen suçların oranının \%15 olduğu ve "denetimli serbestlik tedbiri” kararı verilen tüm hükümlüler arasında ise bu suç türünün üçüncü sırada yer aldığ1 belirlenmiştir (The Probation Service 2016). Bu sonuçlara dayanarak 2016 yılında bir pilot çalışma ile "Bütünleştirilmiş Kamu Hizmeti Programı" uygulaması başlatılmıştır. Bu programda denetimli serbestlik hükümlülerinin kamu hizmetlerinde geçirdiği sürenin 1/3'ünde denetimli serbestlik sürecindeki diğer çeşitli sosyal uyum ve rehabilitasyon programlarına ve destek hizmetlerine katılımları sağlanmıştır (Hamilton 2016, The Probation Service 2016).Suç işleme ve madde kullanım öyküsünün yüksek düzeyde ilişkili olduğu tespit edildiğinden bu sonuçlar, 2016 yllında başlatılan SAOR (Support, Ask and Assess, Offer Assistance, Refer) projesinin de çıkış noktası olmuştur. SAOR projesi, "denetimli serbestlik tedbiri” konulan hükümlüleri tarama, değerlendirme ve destek sağlama gibi uygulamaları (motifleri) içeren "Erken Uyarı Modeli” olarak da adlandırılmaktadır (The Probation Service 2016).

İrlanda'da 1991'de başlayıp 27. yılını dolduran BRIDGE projesi ise denetimli serbestlik hükümlülerin geçmiş yaşantısı ve suç öyküleri araştırılarak, davranış geliştirme grupları, program geliştirme ve kriminolojik davranışların tespiti gibi hizmetleri içeren kanıta dayalı bir yaklaşıma sahiptir (The Probation Service 2017). Görüldüğü üzere İlanda suçun ve "denetimli serbestlik kararı" verilen hükümlülerin sosyal uyuma ve sağaltıma ilişkin uygulamalarını kamu kurumlarının aksine daha çok STK'lara bırakarak, daha fazla psiko-sosyal destek ve toplumsal etkileşim hedefleyen bir denetimli serbestlik politikası gütmektedir (The Probation Service 2015, 2018). Böylelikle İrlanda toplumsal bütünleşme yolu ile suçun yeniden işlenmesinin önüne geçmeyi hedeflemektedir.

\section{Türkiye'de Denetimli Serbestlik SistemiUygulamalan}

Ülkemizde ise denetimli serbestlik uygulamaları, o ilin Adliyesine bağlı olarak Dene- 
timli Serbestlik Müdürlüğü adı altında hizmet veren ve şüpheli, sanık veya hükümlü hakkında 5271 sayılı CMK'nin 109'ncu maddesinin 3'üncü fikrası ve 231'inci maddesinin 8'inci fikrası; 5395 sayılı Çocuk Koruma Kanunun 20'inci maddesi; 5237 sayılı Türk Ceza Kanunun 50'inci maddesinin 1'inci fikrasinın (c),(d),(e) ve (f) bentleri, 53'üncü maddesinin beş ve altıncı fikraları, 58'inci maddesinin 9'uncu fikrası, 221'inci maddesinin 5'inci fikrası; 5275 sayılı Ceza ve Güvenlik Tedbirlerinin İnfazı Hakkında Kanunun 105' inci maddesinin 4'üncü fikrası, 108'inci maddesinin dört ve altıncı fikraları ile 110'uncu maddesinin ikinci fikrası gereğince "adli kontrol" veya "denetimli serbestlik tedbir" kararı verilmesi halinde yerine getirilmektedir (Resmi Gazete 2004, 2005).

\section{Türkiye'deki Denetimli Serbestlik Teşkilat Yapısı}

Ülkemizde 2005 yılında Denetimli Serbestlik uygulamasının hukuksal zemini oluşturulmuş; sonraki yıllarda ise yeni düzenlemeler getirilmeye çalışılmıştır. Denetimli serbestlik, yardım ve koruma hizmetleri, Adalet Bakanlığı Ceza ve Tevkifevleri Genel Müdürlüğü bünyesinde Denetimli Serbestlik Daire Başkanlığı, taşra teşkilatı olarak ise adalet komisyonunun bulunduğu 139 merkezde oluşturulan denetimli serbestlik müdürlükleri ve koruma kurulları tarafindan yürütülmektedir. Denetimli Serbestlik Daire Başkanlığı'nın merkezi yapısı ise, Adalet Bakanlığı ve Ceza ve Tevkifevleri Daire Başkanlığına bağlı olarak 6 kişiden (Adalet Bakanı, Müsteşar, Müsteşar Yardımcısı, Genel Müdür, Genel Müdür Yrd. ve Daire Başkanı) oluşan danışma kurulu yönetiminde iki tetkik hakimine bağlı olarak beş adet şube müdürlügünden oluşmaktadır. Bu şube müdürlükleri, Değerlendirme ve Planlama, Koruma Kurulları ve Mağdur Destek, Elektronik İzleme, İnfaz ve İyileştirme ile Çocuk Hizmetleri şube müdürlüklerinden oluşmaktadır (Resmi Gazete 2005, Milli Eğitim Bakanlığı 2018).

\section{Sistemde Risk ve İhtiyaç Değerlendirme Sistemi ve Planlama}

Denetimli serbestlik büroları, haklarında "denetimli serbestlik tedbir" kararı verilen hükümlülerin denetimlerinin ve sosyal entegrasyon sürecinin sağlanmasında birtakım görevler üstlenirler. Denetimli serbestlik, hükümlünün büroya kaydıyla başlayıp mahkemece belirlenmiş aralıklarla Denetimli Serbestliğin ilgili bölümlere gidip kuruluştaki yapılması gereken süreçlere ve programlara uymalarını zorunlu kılan, psiko-eğitim ve sosyal katılımı etkin olarak kullanmayı hedefleyen bir sosyal iyileştirmede aracı bir kurumdur. Mahkemelerce alınan veya Cumhuriyet savcilikları tarafindan kontrol edilen adli kontrol (denetimli serbestlik) kararları Ulusal Yarg1 A ğ1 Programı (UYAP) aracılığıyla denetimli serbestlik müdürlüklerine ulaştırılmaktadır.

Haklarında "Denetimli Serbestlik Tedbir" kararları verilen hükümlüler 10 günlük kanuni süre içerisinde denetimli serbestlik müdürlüklerine başvurmak zorundadırlar. Aksi takdirde "denetimli serbestlik tedbir" kararı geçerliliğini yitirebilmektedir (Milli Eğitim Bakanlığı 2018). Dolayısıyla haklarında denetimli serbestlik tedbir kararı verilen hükümlülerin "gelen evrak bürosu” aracılığıyla dosyasının ilgili bürolara gönderilmesinin ardından süreç içerisinde izleyeceği yol ve dosya işlemleri şu şekilde ilerlemektedir: Hükümlü "Kayıt Kabul Bürosu'na” ulaşarak kaydını yaptırmaktadır. Daha sonra "Değerlendirme ve Planlama Bürosu” hükümlünün risk ve ihtiyaçlarının belirlenmesi görevini üstlenmekte ve hükümlünün değerlendirilmesi bu büroda yapılmaktadır. Kullanılan değerlendirme envanterleri sayesinde hükümlüler, çeşitli risk faktörleri açısından incele- 
nerek, gelecekte yaşanması muhtemel suç potansiyellerine göre sınıflandırılmaktadır. Denetimli Serbestlik Komisyonu, birey ile ilgili kararını verdikten sonra cezanın infazına başlanmaktadır. DS sürecine İnfaz sırasında eğitim ve iyileştirme çalışmaları yürütülebilir (Işık 2015).

\section{“Tedavi ve Denetimli Serbestlik Tedbiri” Kararı Verilen Hükümlüler Hakkında Sağlık Kuruluşlarında Yapılan Uygulamalar}

Hükümlünün/Hastanın sağlık kuruluşuna başvurusundan son raporu verilinceye kadar geçen süreçteki tüm uygulamalar ve işlemler için gerekli takip sistemleri ilgili sağlık kuruluşunda yapılmaktadır. Hükümlünün/Hastanın ilgili hastaneye sevk evrakının geçerlilik süresi beş iş günüdür. Hasta beş iş günü bitimi sonrasında geldiği takdirde, tedaviye alınır. Ayrıca hükümlünün beş iş günü içerisinde sağlık kuruluşuna başvurmaması tedaviye alınmasına engel teşkil etmemektedir (Sağlık Bakanlığı 2015).

Sağlık kuruluşunda, başvuruda bulunan hükümlünün/hastanın, ilk görüşmede psikiyatrik değerlendirmesi ve muayenesi yapılmakta ve klinik görüşmeler ile idrar, kan, tükürük, ter, kıl vb. numunelerle yapılan uyuşturucu ve uyarıcı madde biyolojik numune testlerini bir arada değerlendirilerek hastanın tedavi programı oluşturulmaktadır. Gerekli görüldüğü durumlarda ilaç ve/veya psikoterapi gibi ayaktan kısa müdahalelerde de bulunulmaktadır. Hekim, denetimli serbestlik hastasına tedavi süreciyle ilgili, oluşturulan tedavi programı hakkında ve denetimli serbestlik tedavi hizmeti kuralları hakkında bilgi de vermektedir. Ayrıca hastanın tedavi sürecine uymaması halinde Türk Ceza Kanunu'nun 191. maddesi kapsamında verilen “Tedavi ve Denetimli Serbestlik Tedbiri” kararının hükümlüye çeşitli yükümlülükler getirdiği bilgisi de verilmektedir (Sağlık Bakanlığ1 2015).

Tablo 1. Çocuk ve yetişkinlere verilen "tedavi ve denetimli serbestlik tedbiri" kararlarının yıllara göre dağılımı

\begin{tabular}{|l|c|c|c|}
\hline Tedavi ve denetimli serbestlik (TCK 191. Madde)/YIl & Erişkin & Çocuk & Toplam \\
\hline 2013 & 1.295 .720 & 99.057 & 1.394 .777 \\
\hline 2014 & 1.279 .632 & 105.957 & 1.385 .589 \\
\hline 2015 & 1.122 .986 & 87.842 & 1.210 .828 \\
\hline 2016 & 792.903 & 56.364 & 849.267 \\
\hline 2017 & 600.572 & 39.011 & 639.583 \\
\hline 2018 (illk9 ay) & 513.336 & 27.418 & 540.984 \\
\hline Toplam & 5.605 .149 & 415.649 & 6.021 .028 \\
\hline
\end{tabular}

Bu yükümlülükler şunlardır:

Eğer hükümlü; "Kullanmak için uyuşturucu veya uyarıcı madde satın alır, kabul eder veya bulundurur ya da uyuşturucu veya uyarıcı madde kullanırsa, iki yıldan beş yıla kadar hapis cezası ile cezalandırılabilir.” Ayrıca, "Tedavi ve Denetimli Serbestlik Tedbiri uygulamasından sonra beş yıl boyunca bu kapsamdaki suçlardan tekrar yakalanırsa, ceza infazının gerçekleşebileceği” bilgisi de hükümlüye verilmektedir.

İlgili sağlık kuruluşunda hastanın tedavi giderlerinin tamamı, sosyal güvencesi olması halinde bağlı olduğu Sosyal Güvenlik Kurumundan; sosyal güvencesi olmaması halinde ise Sağlık Bakanlığının ilgili mevzuatına göre karşılanması için işlem yapılmakta ve ilgili tıbbi kanaat raporlan düzenlenmekte ve Denetimli Serbestlik Müdürlüklerine belirtilen sürelerde gönderilmektedir (Sağlık Bakanlığ1 2015)

Ülkemizde söz konusu yasa maddesinin hükmüne göre alınan "tedavi ve denetimli serbestlik tedbiri” kararları Tablo 1 ve Tablo 2 ye göre son yillarda giderek azalma 
göstermektedir. Bu durum 15 Temmuz 2016'da Türk Silahlı Kuvvetlerinin içine sızan terör örgütü üyeleri tarafından gerçekleştirilen darbe girişiminin ardından cezaevlerindeki hükümlülere verilen adli kontrol sayılarında artma ve buna bağlı olarak tedavi ve denetimli serbestlik kararlarında azalma gözlenmiştir. Adli kontrol ile birlikte haklarında "tedavi ve denetimli serbestlik karar sayılarında meydana gelen değişikliklerin ülkemizdeki denetimli serbestlik hizmetlerinin 13 yıl gibi kısa bir geçmişe sahip olması ve bu alanda uzman personel sayısındaki yetersizliklerden dolayı meydana geldiği düşünülmektedir (Zorlu 2014, Milli Eğitim Bakanlığı 2018).

Tablo 2. Çocuk ve yetişkinlere verilen "tedavi ve denetimli serbestlik tedbiri" kararlarının 2018 aylarında dağııımı

\begin{tabular}{|l|c|c|c|}
\hline Tedavi ve denetimli serbestlik (TCK 191. Madde) / Ay & Erişkin & Çocuk & Toplam \\
\hline Ocak & 52.285 & 3.063 & 55.348 \\
\hline Şubat & 54.357 & 3.174 & 57.531 \\
\hline Mart & 55.624 & 3.200 & 58.824 \\
\hline Nisan & 56.029 & 3.112 & 59.141 \\
\hline Mayls & 57.372 & 3.104 & 60.476 \\
\hline Haziran & 58.333 & 3.047 & 61.380 \\
\hline Temmuz & 59.546 & 3.037 & 62.583 \\
\hline Ağustos & 59.572 & 2.836 & 62.628 \\
\hline Eylül & 60.218 & 2.845 & 63.063 \\
\hline
\end{tabular}

Eğitim ve İyileştirme Çalışmalan

Denetimli Serbestlik Müdürlüklerinde risk ve ihtiyaç değerlendirmeleri sonucunda veya mahkeme tarafindan rehberlik çalı̧̧malarına hükmedilmesi durumunda hükümlünün ihtiyaçlarına uygun iyileştirme çalışmaları yapılmaktadır (Milli Eğitim Bakanlığı 2018). Hükümlülerle bireysel görüşme, grup çalışması ve serbest zamanların değerlendirilmesi gibi iyileştirme ve eğitime yönelik hizmetler eğitim ve iyileştirme bürolarında görevli denetimli serbestlik uzmanları tarafından yürütülmektedir (Milli Eğitim Bakanlığ1 2018). Hükümlülerin, ruhsal, sosyal ve benzeri durumlarına göre özel gereksinimleri dikkate alınarak yerleştirildikleri "Öfke Kontrolü Programı", "Hayat için Değişim Programı” vb. programlar sayesinde, sosyal yaşamın bir provası olan denetimli serbestlik süreci içerisinde tedavi ve rehabilitasyonları gerçekleştirilerek sağlıklı bir şekilde topluma entegrasyonları sağlanmaya çalışılmaktadır. Böylelikle hükümlülerin günlük hayatta karşılaştıkları problemlere verecekleri tepkiler üzerine de çalışılabilmektedir. Ayrıca hükümlülerin bu süreçte yaşadıkları aile ve sosyal çevreleri içerisinde olaylara verecekleri tepkilerin provasının yapılması imkânı da doğmaktadır (Işık 2015)

\section{Denetim, Takip ve Elektronik İzleme}

"Denetimli Serbestlik Tedbir" kararı sürecinde, eğitim ve iyileştirme çalışmaları sırasında sorumluluklarını yerine getirip getirmedikleri "Denetim Bürosu" tarafindan takip edilmektedir (Yıldız ve Tiryaki 2015). Tedavi ve denetimli serbestlik tedbiri kararı dışında verilen diğer hükümlüler denetimli serbestlik sürecinde eğitim ve iyileştirme çalışmalarına dahil edilmemektedir. Sonuç olarak "Denetim Bürosu"nun sorumluluklar1, hükümlünün, mahkeme tarafindan verilen "Denetimli Serbestlik Tedbir" kararına uyup uymadığının tespitini içermektedir (Milli Eğitim Bakanlığı 2018).

Tedavi ve denetimli serbestlik tedbiri kararı verilen uyuşturucu kullanıcısı/bağımlısı bireylerin denetim planı hazırlanmamaktadır. Onun yerine bireyin uyması gereken kuralları ve dikkat etmesi gereken durumları içeren bilgilendirme formu hükümlülere verilmektedir (Milli Eğitim Bakanlığı 2018, Orum ve ark. 2018). Denetimli Serbestlik 
Tedbir kararına ilişkin rapor ise hükümlünün risk düzeyi ve ihtiyaçları, kişisel özellikleri, beceri ve yetenekleri, tercihleri ve ilgi alanları, uzmanın hükümlüye ilişkin gözlem ve değerlendirmelerini de kapsayan ve hükümlünün denetimli serbestlik süreci boyunca, iyileştirme programlarındaki edinimlerini de içeren topluma uyum başarısı, olumsuz davranışlarını değiştirmek vb. çabalarının ve genel gelişiminin değerlendirildiği raporlardır. Uyuşturucu madde kullanıcısı/bağımlısı bireylere verilen "Tedavi ve Denetimli Serbestlik Tedbir” kararı verilen hükümlülerin yükümlülükleri için her üç ayda bir denetim raporu hazırlanmaktadır (Milli Eğitim Bakanlığı 2018, Orum ve ark. 2018). Denetim planları hükümlünün risk ve ihtiyaçları göz önünde bulundurularak en geç altı ayda bir vaka sorumlusu tarafından yeniden hazırlanmaktadır (Milli Eğitim Bakanlığı 2018).Denetim bürosunun bir başka görevi ise hakkında takip kararı çıkmış hükümlülerin elektronik izlenmesi, denetimi ve takibinin yapılmasıdır. Denetim bürosu bireylere takılan elektronik izleme işlemlerini büroda görevli denetimli serbestlik memurları ile kolluk kuvvetleri işbirliği içinde yürütmektedirler (Işık 2015, Milli Eğitim Bakanlığ1 2018).

Ülkemizde verilen bir diğer denetimli serbestlik hizmeti ise mağdur destek hizmetleridir. Denetimli Serbestlik mevzuatında mağdur kavramı ilk kez 5 Mart 2013 tarihli ve 28578 sayılı Resmi Gazetede yayımlanan "Denetimli Serbestlik Hizmetleri Yönetmeliği”nde belirlenmiştir (Milli Eğitim Bakanlığı 2018). Mağdur, Denetimli Serbestlik Müdürlüğüne başvurduğunda öncelikle kayıt işlemleri tamamlanmakta, sonrasında ise mağdur, mağdur destek hizmetleri bürosuna yönlendirilmektedir. Mağdur bireyin denetimli serbestlik müdürlüğüne başvurusunun alınması, ilk bilgilendirme, değerlendirme planlama bürosunca risk ve ihtiyaçlarının belirlenmesi, kişi hakkında adli makamlarca verilmiş olan karar ve değerlendirme neticesi dikkate alınarak bir denetim planının oluşturulması, kişinin infaz ve iyileştirme bürolarınca yürütülmekte olan bireysel görüşme, grup çalışması ve seminer vb. programlara dahil edilmesi, kişi hakkındaki denetim ve takip çalışmalarına başlanması ve infaz süresinin tamamlanması ile sürecin sonlandırılması şeklinde yerine getirilmektedir (Işı1 2015). Bu bürodaki uzmanlar tarafindan mağdurun ihtiyaçları belirlenmekte ve destek alacağı ilgili kurum, kuruluş veya STK'ya yönlendirilmektedir. Mağdurun talep etmesi halinde yargılama süreci hakkında bilgilendirilmekte yapılabilmekte, gereken psiko-sosyal destek programları uygulanabilmekte ve ayni veya nakdi, eğitim, sağlık gibi yardımlar da yapılabilmektedir.

\section{Tartışma}

Ülkelerin denetimli serbestlik modelleri karşılaştırıldığı zaman çoğunlukla süreçler birbirlerine benzese de her ülkenin suç olgusuna, suçluluğa ve hükümlüsüne bakış açısı genel anlamda denetimli serbestlik politikalarını da değiştirebilmektedir. Ülkelerin denetimli serbestlik modelleri ve modellerin içerisinde bulunan araçlar ve personellerden kaynaklanan birbirinden farklı tartışma konuları ortaya çıkabilmektedir.

Çalışmamızda, ABD ve Almanya bölgesel yönetim şekillerince özelleşen ceza adalet sistemi anlayışları, alkol bağımlılığından kaynaklı suç oranlarının yüksek olduğu bir ülke olan İrlanda’nın bu problemin çözümüne yönelik denetimli serbestlik yaklaşımları ve ülkemizdeki "Mahkemece belirtilen koşullar ve süre içinde, denetim ve denetleme planı doğrultusunda şüpheli, sanık veya hükümlünün sosyal uyumunun sağlanması ve toplumla bütünleşmesi açısından ihtiyaç duyduğu her türlü hizmet, program ve kaynakların sağlandığı toplum temelli "Denetimli Serbestlik Sistemi uygulamaları" nedeniyle adı 
geçen ülkeler karşılaştırılmış ve birtakım önerilerde bulunulmuştur.

Bölgesel yönetim şekillerince özelleşen ceza adalet sistemi anlayışına sahip ABD modelinde, denetimli serbestlik tedbir kararı verilen hükümlünün risk değerlendirme, tedavileri planlanırken risk değerlendirmeleri sonucu uygun görülen rehabilitasyon süreçleri hükümlünün sosyal güvenlik (sigorta) kapsamına göre değişiklik gösterebilmektedir. ABD'nin Florida, Kentucky, Missouri ve Tennessee eyaletlerinde denetimli serbestlik hükümlüleriyle yapılan bir çalışmaya göre (Teague 2016), bu bölgelerdeki özel, denetimli serbestlik kuruluşlarının hükümlülerden denetimli serbestlik hizmetleri karş1lığında yüklü miktarlarda ödeme talep ettiği tespit edilmiştir. Böylelikle halihazırda düşük sosyoekonomik düzeye sahip bireylerin, denetimli serbestlik giderlerini de karş1layabilmesi neredeyse imkânsız hale gelmektedir. Dolayısıyla, hükümlüler, özel denetimli serbestlik kuruluşlarına olan borçlarını ödeyebilmek adına tekrar suça yönelebilmektedirler (Teague 2016, Human Rights Watch 2018). Çalışmamızda incelenen ülkelerin denetimli serbestlik sistemlerinde toplum temelli kuruluşların/STK'ların süreç içerisindeki rolleri büyüktür. Ancak, özel denetimli serbestlik kuruluşlarının hükümlülerden denetimli serbestlik hizmetleri karşıllğında ücret talep ettiği ABD'deki finansal anlayışa karşın, Almanya ve İrlanda'daki denetimli serbestlik uygulamalarında, bireylerin işledikleri çeşitli suçlardan dolayı ilgili mahkemeler tarafından para cezası gibi cezai yaptırımların verilmesi dışında denetimli serbestlik sürecinde hükümlülerden herhangi bir ücret talep edilmemektedir. Ayrıca Almanya ve İrlanda da rehabilitasyon hizmetleri ve toplumsal bütünleşmeyi sağlayan projeler de hükümlüler için maddi bir yük oluşturmamaktadır (Jehle 2015, The Probation Service 2017). Ülkemizdeki denetimli serbestlik hizmetlerinde; "5275 sayılı Ceza ve Güvenlik Tedbirlerinin İnfazı Hakkındaki Kanununun, Hükümlünün Muayene ve Tedavisi bölümünün 78. maddesinin 2. fikrasına göre; Sağlık Bakanlığı ve Çalışma, Sosyal Hizmetler ve Aile Bakanlığı ile üniversitelerin sağlık kuruluşları, hükümlülerin tedavileri bakımından gerekli yardımları yapmakla görevlidirler" (Sağlık Bakanlığı 2015) hükümlülere maddi açıdan bir yük getirmemektedir. Dahası, Denetimli Serbestlik Müdürlüklerindeki sosyal çalışmacılar tarafından yapılan değerlendirmeler sonucunda, denetimli serbestlik hükümlülerinin ve ailesinin maddi desteğe ihtiyacı olduğu raporlarla tespit edilip bulundukları illerdeki Mülki İdare amirliklerine (Valiliğe) bağlı olan Sosyal Yardımlaşma ve Dayanışma Vakfı Müdürlüklerine başvurulmakta ve hükümlü ve ailesine maddi destek sağlanmaktadır. Ancak hükümlülerinin ve ailesinin maddi desteğe ihtiyacı olduğu sosyal inceleme raporlarının ilgili mahkemelere gönderilmesi ve mahkemelerden adı geçen bireyler için "Ayni-Nakti Yardım Tedbiri” kararının çıkarılması ve bu kararın Valiliklere, Kaymakamlıklara bildirilmesi tek elden standart hale gelmesini sağlayacaktır. Böylelikle hükümlü ve ailesine maddi destek sağlama hızlandırılmış olacaktır. Sonuç olarak ülkemizde tüm denetimli serbestlik hizmetlerinin devlet idaresinde bulunması ve STK'ların da gönüllülük esasıyla hareket etmesinden dolayı süreç, hükümlülerin kriminojenik olmayan ihtiyaçlarını maddi bir bedel olmadan karşılamaktadır.

Bölgesel yönetim şekillerince özelleşen ceza adalet sistemi anlayışına sahip olmasına rağmen ABD'nin denetimli serbestlik hizmetleri anlayışına göre hükümlüler ile denetimli serbestlik personelleri arasındaki empatik ilişkinin "risk-ihtiyaç-duyarlılık" sistemine çok fazla önem verilmekte ve uygulamada çok olumlu katkı sağladığı düşünülmektedir. $\mathrm{Bu}$ anlayışa göre empatik yaklaşımın hem hükümlülere iletişim becerileri kazandırmak adına verilen psiko-eğitim uygulamalarında hem de denetim süreci bo- 
yunca korunması gerekmektedir. Ancak verilen psiko-eğitim hizmetleri kapsamında "uygun tepkinin" ya da olumlu iletişim tekniklerinin her hükümlünün ihtiyacını karşılayıp karşılamadığı bir tartışma konusu olmuştur. Aynı şekilde "risk-ihtiyaç-duyarlılık" sistemine entegre olmuş her denetimli serbestlik personelinin bu sistemin gerektirdiği becerileri kavrayıp içselleştirerek, uygulamaya koyabildiği hususunda da tartışmalar mevcuttur. Bu konuda personellere uygun empatik becerilerde bulunup bulunmadikları konusuna ilişkin bu konunun uzmanları tarafından geribildirimler (süpervizyon) verilmesi ve verimliliğin arttırılması için denetimli serbestlik personellerine belirli aralıklarla oryantasyon programlarının yapılması önerilmektedir (Alexander ve ark. 2014).

Hükümlü ile personel arasındaki iletişimin olumluluğunu etkileyen faktörlere bakıldığında hükümlülere verilen hizmetlerin niteliğini incelemek adına yapılan süpervizyonun etkili olduğuna yönelik çalı̧̧malar bulunmaktadır. Bu araştırmalara göre, denetimli serbestlik personelleri, süpervizyon eksikliğinin rol karmaşasına sebep olabileceğini ifade ettikleri, kendilerine, kişilik bozuklukları olan hükümlülere yönelik de klinik süpervizyon verilmesinin de sürece daha olumlu etki edebileceğini belirtmektedirler. İrlanda ve Almanya modelinde denetimli serbestlik personellerine klinik süpervizyon verilmekte, ülkemizde ise personellere bu eğitimler şimdilik yerel eğitim projeleri bazında verilmektedir. Dolayısıyla bu iki ülkenin süpervizyon sistemi, bu noktada farklılaşma göstermektedir (O'Connell 2005, Subramanian and Shames 2013, Wood and Brown 2014).

Ülkemizde denetimli serbestlik personeli, hükümlüler hakkında ilgili mahkemeler tarafından verilen "tedavi ve denetimli serbestlik tedbiri" kararına göre mevcut yaptırımların uygulanması ve hükümlülere verilecek olan iyileştirmeye yönelik rehabilitasyon ve sosyal uyum çalışmalarının yapılması konusunda (örneğin hükümlüler ile bireysel görüşmelerde hangi terapötik ilke ve teknikleri kullanacakları) hangi yaklaşım modellerini seçecekleri konusunda kararsızlık yaşamaktadırlar. Kaldı ki ülkemizde terapötik olarak hükümlü ile psikolojik danışmanlık anlamında bireysel ya da grup oturumları düzenleyecek, sosyal uyum ve rehabilitasyon uygulamalarını yürütecek ilgili uzman personelin yetersizliği bu sürecin daha da zorlaşmasına ve verimsiz geçmesine neden olabilmektedir (Wood ve Brown 2014, Zorlu 2014, Altın 2015). Bu durum, Almanya'daki sistemden farklı olarak, ülkemizde denetimli serbestlik personellerinin yetkinliklerine göre görev tanımlarının yapılmamasından kaynaklandığı düşünülmektedir. Yapılan çalışmalarda ise personelin rol çatışması yaşamasının personelin tükenmişliği ile doğru orantılı olduğu bulunmuştur (Allard ve ark. 2010, Altın 2015).

Ceza infaz yöntemlerinin başarısı suçun yeniden işlenmesi ya da tekrarı ile incelenmektedir. Bu açıdan bakılacak olursak ABD, Almanya ve İrlanda'daki denetimli serbestlik hükümlülerinin yeniden suç işleme oranları, denetimli serbestlik anlayışlarının etkililiği konusunda fikir verebilmektedir. Jehle'nin (2015) yaptığı bir çalışmaya göre Almanya'da 2011 yllında Denetimli Serbestlik sürecini yeniden suç işleme sebebiyle tamamlayamayanların oranı \%29 iken İrlanda'da bu oran 2012 ve 2015 yılları arasındaki 3 yillık takip sonucu \%37 olarak tespit edilmiştir (Jehle 2015, The Probation Service 2015). ABD'deki denetimli serbestlik süreci sırasında ya da sonrasında meydana gelen yeniden suç işleme oranları ise ilk üç y1 içinde \%35 iken ilk beş yılda bu oranın \%43'e yükseldiği belirlenmiştir (Markman ve ark. 2016). Dolayısıyla adı geçen ülkelerin uyguladıkları denetimli serbestlik sistemlerinde, hükümlünün sosyal uyuma yönelik ihtiyaçlarını ve kriminojenik olmayan gereksinimlerini (fiziksel, duygusal) daha çok gözeten ülkeler, hükümlülerin yeniden suç işlenmesini azaltma anlamında nispeten daha avan- 
tajlı oldukları söylenebilmektedir.

\section{Sonuç}

ABD, Almanya, İrlanda ve Türkiye'deki denetimli serbestlik sistemleri karşılaştırıld1ğında ülkemizde denetimli serbestlik hizmetleri tarihi oldukça kısa bir geçmişe sahiptir. Dolayısıyla denetimli serbestlik sisteminin ülkemizdeki kısa tarihi, gerek mevzuat ve gerekse uygulama sonuçları bakımından irdelendiğinde, karşılaştırmalı hukukta yüzyıllar alan sürecin ülkemizde çok hızlı bir şekilde yaşandığı görülmektedir. Bu da kaçınılmaz olarak bu alanda, birçok önemli soru ve sorunlarla yüz yüze gelinmesine neden olunmaktadır. Bu nedenle uygulanabilirliği yüksek ve başarıyı arttıracak (yeniden suç işlemeyi azaltacak) kanun, tüzük, yönetmelikler ve genelgelerin tekrar gözden geçirilmesi, gereksinime göre yeni düzenlemeler getirilmeli ve yıllar içerisinde ihtiyaca göre güncellenmelidir.

ABD'de ve Almanya'da bölgesel ve bölgelere göre kısmen farklllıklar göstermesinin aksine İrlanda'da ve ülkemizde tek tip denetimli serbestlik sistemi uygulanmaktadır. Ülkemizde uygulamalar sırasında hem riski yüksek şehirlerde riski azaltmaya yönelik çalışmalar hem de koruyucu-önleyici çalışmalar yapılmalıdır. Ancak, riski düşük şehirlerde ise koruyucu-önleyici çalı̧̧malara daha fazla ağırlık verilmelidir. Ayrıca ülkemizde "yeniden suç işleme" oranlarıyla ilgili olarak ölçülebilir bir veri sistemi oluşturulması, suçun tekrar işlenmesine neden olan risk faktörlerinin belirlenmesi açısından önemlidir.

Denetimli serbestlik hizmetleri stresli çalışmaları içerdiğinden zor bir çalışma alanıdır. Denetimli serbestlik personeli tarafından, hükümlüler hakkında verilen mahkeme kararlarının uygulanması belirli kurallara ve yaptırımlara uygun davranmayı gerektirmektedir. Öte yandan uygulamalar, tedavi ve iyileştirmeye yönelik olarak yürütülmeye çalışılmaktadır. Bu durum, kişiden kişiye rehabilitasyona yönelik bir yaklaşım ile cezalandırıcı bir yaklaşım sergileme durumlarından hangisinin daha öncelikli olduğunun belirlenememesi personelin belirsizlik yaşamasına neden olabilmektedir. Ancak personelin rol çatışması yaşaması, hangi tür yaklaşımın daha baskın olduğundan bağımsız olarak ortaya çıkmaktadır (Allard ve ark. 2010). Personelin iyi eğitim almış uzmanlar olmasının yanında, çalışma ve iletişim becerilerini olumsuz yönde etkileyecek kurum içi etkenlerden de azami ölçüde korunarak hizmet sunabilmeleri için gerekli imkânların sağlanması gerekmektedir.

Personelin gerekli temel becerilerinin lisans eğitimlerinde yer aldığı göz önünde bulundurularak, denetimli serbestliğin temel odak noktasının artık rehabilitasyon olduğunu da dikkate alarak eğitim programları geliştirmenin yanında, sadece güvenliğe değil aynı zamanda etik ilkelere de odaklanılmalıdır. Eğitimlerden sonra personelin edindiği becerileri kullanıp kullanmadıklarına yönelik takip eğitimlerinin düzenlenmesi, eğiticilerin işyerlerine gidilerek uygulamaların değerlendirilmesi sağlanmalıdır.

Eğitim ve süpervizyon denetimli serbestlik sisteminde, sürece olumlu katkı sağlayabilecek faktörler arasında görülmektedir. Denetimli serbestlik hizmetlerinde dünya genelinde personel eğitimi konusunda farklılıklar göze çarpmakta, Türkiye'de ise denetimli serbestlik personelinin eğitimine önem verildiği ve çok sayıda hizmet içi eğitim ile personel eğitimi ve gelişiminin desteklendiği görülmektedir.

Denetimli serbestlik görevlilerinin sayısının artırılması, kişi başına düşen dosya sayısının sınırlanması ve klasik memur-mesai çalışma sisteminden farklı olarak esnek bir çalışma pratiğine kavuşturulmaları sistemin başarısı için bir zorunluluktur. 
Denetimli serbestlik uzmanları yetiştirilebilmesi için ülkemizde üniversitelerde "Bağımlılık ve Adli Bilimler” alanında yüksek lisans ve doktora programları açılmıştır. Bu alanlardaki programların Ulusal bazda yaygınlaştırılması ve adı geçen programlardan mezun olanların denetimli serbestlik müdürlüklerinde uzman olarak görevlendirilmelerinin denetimli serbestlik sürecinin niteliğini olumlu yönde etkileyeceği düşünülmektedir.

Ceza adalet sistemimizin içinde bulunduğu durum her ne kadar birçok önemli sorunla baş edilmesi konusunda kanun koyucu ve uygulayıcılara kaçınılamaz bir yükümlülük yüklese de; suçluyu bulmaya ve cezalandırmaya değil, masumiyetin kaynağı olan "insan" 1 keşfetmeye odaklanan ve sonuna kadar onların rehabilitasyonu için bir çaba mekanizması olan denetimli serbestlik sisteminin varlığı ve kısa sürede aldığı yol dikkate alındığında gelecekten umutlu olmamızı sağlamaktadır.

$\mathrm{Bu}$ çalışma ile denetimli serbestlik sistemlerinin farklı uygulamalarının ortaya konulması tıpkı dünyada olduğu gibi ülkemizde de suç ve yeniden suç işleme riskinin azaltılması konusunda denetimli serbestlik sürecindeki personelin hükümlülerle kurduğu iletişimin niteliği, hükümlü profillerine yönelik farkındalıkları ve en önemlisi de hükümlülerin suça yeniden yönelmelerini azaltmak anlamında gelecekte yapilacak araştırmalara yol göstericilik konusunda katkı sağlayacağı düşünülmektedir.

\section{Kaynaklar}

$\S \S 29$ Law on Traffic in Narcotics BtMG (2018) Offenses. Berlin, Federal Law Gazette [Bundesgesetzblatt].

$\S \S 31$ a Law on Traffic in Narcotics BtMG (2018) Refrain from the persecution. Berlin, Federal Law Gazette [Bundesgesetzblatt].

$\S \S 35$ Law on Traffic in Narcotics BtMG (2018) Withdrawal of the sentence. Berlin, Federal Law Gazette [Bundesgesetzblatt].

$\S \S 36$ Law on Traffic in Narcotics BtMG (2018) Credit and suspension for probation. Berlin, Federal Law Gazette

[Bundesgesetzblatt].

\$21 German Youth Courts Law (2017) Suspension of sentence. Berlin, Federal Law Gazette [Bundesgesetzblatt].

$\$ 56$ German Criminal Code StGB (2013) Power of court to suspend sentence. Berlin, Federal Law Gazette [Bundesgesetzblatt].

\$67b German Criminal Code StGB (2013) Immediate order for suspended measure. Berlin, Federal Law Gazette [Bundesgesetzblatt].

18 U.S. Code $\$ 3563$ (1987) Conditions of probation. Washington D.C., US Government.

Akbaş GE, Mutlu E (2016) Madde bağımllı̆̆ı tedavisi gören kişilerin bağımllık ve tedavi deneyimleri. Toplum ve Sosyal Hizmet, 27:1-33.

Alexander M, Lowenkamp CT, Robinson C (2014) Probation and parole practices. In Encyclopedia of Criminology and Criminal Justice (Eds G Bruinsma, D Weisburd):3973-3979. New York, Springer.

Allard TJ, Wortley RK, Stewart AL (2003) Role conflict in community corrections. Psychol Crime Law, 9:279-289.

Altın D (2015) Denetimli serbestlik hizmetlerinde personel gelişimi ve eğitimine genel bakış. In Türkiye'de Denetimli Serbestlik 10. YII Uluslararası Sempozyumu, Uluslararası Yaklaşımlar (Ed D Ozyoruk):1-7. Ankara, T.C. Ceza ve Tevkif Evleri Genel Müdürlüğï.

Asthal BS (2006) Ingiltere ceza sisteminden sorumlu Devlet Bakanı Baroness Scotland of Asthal'ın konuşma metni. In Türkiye'de Denetimli Serbestlik Hizmetlerinin Geliştirilmesi Projesi Açllı̧ Konuşma Metinleri. Ankara, Adalet Bakanlığı Yayınları.

Burrell WD (2010) Probation in the United States. Transnational Criminology, 3:721-739.

Ceza ve Tevkif Evleri Genel Müdürlüğü (2009) Çocuk ve Genç Adalet Sistemi Almanya Çalışma Ziyareti Raporu. Ankara, T.C. Ceza ve Tevkif Evleri Genel Müdürlügü.

Clarke A, Eustace A (2016) Review of Drug and Alcohol Treatment Services for Adult Offenders in Prison and in the Community. Dublin, Eustace Patterson Limited.

Coester M, Marks E (2009) International Perspectives of Crime Prevention 2, Contributions from The 2nd Annual International Forum. Mönchengladbach, Forum Verlag Godesberg $\mathrm{GmbH}$.

Cullen FT, Jonson CL, Nagin DS (2011) Prisons do not reduce recidivism: The high cost of ignoring science. Prison J.. 91(suppl 3):48S-65S.

Décarpes P, Durnescu I (2014) Probation and community sanctions. In Encyclopedia of Criminology and Criminal Justice (Eds G 
Bruinsma, D Weisburd):3957-3963. New York, Springer.

Dessecker A (2012) Research on offender supervision practice in Germany: a review. Wiesbaden: KrimZ, Posjećeno, 12:1-116.

Geiran V (2011) Defining what we do: the meaning of 'supervision'in probation. Irish Probation Journal, 8:6-27.

Gendreau P, Smith P, French SA (2006) The theory of effective correctional intervention: Empirical status and future directions. In

Taking Stock: The Status of Criminological Theory (Eds FT Cullen, M Coleman):419-446. Piscataway, NJ: Transaction Press.

Hamilton S (2016) Reset: An opportunity to enhance offender resettlement and rehabilitation through mentoring. Irish Probation Journal, 13:134-142.

Human Rights Watch (2018) "Set up to Fail" The Impact of Offender-Funded Private Probation on the Poor. Washington D.C., Human Rights Watch.

Işık E (2015) Türkiye'de denetimli serbestlik uygulamaları. In Türkiye'de Denetimli Serbestlik 10. Yıl Uluslararası Sempozyumu, Uluslararası Yaklaşımlar (Ed D Ozyoruk):1-7. Ankara, T.C. Ceza ve Tevkif Evleri Genel Müdürlüğg̈..

Jehle JM (2015) Criminal Justice in Germany: Facts and Figures, 6th edition. Berlin, Federal Ministry of Justice and Consumer Protection.

Loschnig-Gspandl M, Kilchling M (1997) Victim/offender mediation and victim compensation in Austria and Germany: Stocktaking and perspectives for future research. European Journal of Crime, Criminal Law and Criminal Justice, 5:58-78.

Markman JA, Durose MR, Rantala RR, Tiedt AD (2016) Recidivism of offenders placed on federal community supervision in 2005: Patterns from 2005 to 2010. Bur Justice Stat Spec Rep, 1-16.

Martyn M (2012) Drug and alcohol misuse among adult offenders on probation supervision: findings from the 'Drugs and Alcohol Survey 2011'. Irish Probation Journal, 9:75-92.

Mckenzie DL (2002) Probation and parole: history, goals, and decision-making. In Encylopedia of Crime and Justice (Ed J Dressler). New York, MacMillan.

Miller J (2015) Contemporary modes of probation officer supervision: The triumph of the "synthetic" officer? Justice Q, 32:314336.

Milli Eğitim Bakanlığı (2018) Adalet: Denetimli Serbestlik Bürosu Gözlem Işlemleri. Ankara, Milli Eğitim Bakanlığı.

Mutz I (2008) Germany. In Probation in Europe (Eds AM van Kalmthout, I Durnescu):381-417. Nijmenegen, NL, Wolf Legal Publishers.

Mutz J (2009) Welcome speech for the Workshop Probation meets Prevention within the German Congress on Crime Prevention. In International Perspectives of Crime Prevention 2 Contributions from the 2nd Annual International Forum (Eds M Coester, E Marks): 137-141. Monchengladbach, Verlag Godesberg GmbH.

$O^{\prime}$ Connell S (2005) Staff supervision within the probation and wellfare service (Doctoral dissertation). Dublin, University of Dublin.

Örüm MH, Kara MZ, Eğilmez OB, Özen ME, Kalenderoğlu A (2018) Evaluation of probation implementations of drug users in Adiyaman University training and research hospital: A one-year retrospective study. Medicine Science, 7:1-5.

Resmi Gazete (2004) Ceza ve Güvenlik Tedbirlerinin Infazı Hakkında Kanun No. 5275, 29.12.2004. Ankara, TC Başbakanlık.

Resmi Gazete (2005) Denetimli Serbestlik Hizmetleri Kanunu No. 5402, 03.07.2005. Ankara, TC Başbakanlık.

Sağlık Bakanlı̆ı (2015) Sağlık Hizmetleri Genel Müdürlüğ̈̈, 23 Mart 2015 Tarih ve 14500235/010.06.02/450 Sayllı, Denetimli Serbestlik Tedavi Hizmetleri 2015/11 Genelgesi. Ankara, T.C. Sağılk Bakanlığı.

Smith P, Gendreau P, Goggin C (2002) The Effects of Prison Sentences and Intermediate Sanctions on Recidivism: General Effects and Individual Differences. Ottawa, ON, Public Works and Government Services Canada.

Subramanian R, Shames A (2013) Sentencing and Prison Practices in Germany and The Netherlands: Implications for the United States Center on Sentencing and Corrections. New York, NY, Vera Institute of Justice.

Teague M (2016) Profiting from the poor: Offender-funded probation in the USA. British Journal of Community Justice, 14:99-111.

The Probation Service (2015) Annual Report 2015. Dublin, The Probation Service, 2015.

The Probation Service (2016) Annual Report 2016. Dublin, The Probation Service, 2016.

The Probation Service (2017) Annual Report 2017. Dublin, The Probation Service, 2017.

The Probation Service (2018) Assessment for probation supervision. Available from http://www.probation.ie/EN/PB/ WebPages/ WP16000033 (Accessed: 18.04.2018)

Tongzhi Y (2008) Contemporary recidivism and its control in China. In 135th International Senior Seminar Participants' Papers, 109-114.

Trotter C (1996) The impact of different supervision practices in community corrections: cause for optimism. Aust N Z J Criminol, 29:29-46.

Tuncer G, Duru MN (2011) İ̧ doyumu denetimli serbestlik şubelerinde çalışan personel örneği. İstanbul Aydın Üniversitesi Dergisi (IAÜD), 10:115-142.

United States v. Carter (1998) 159 F3d 397 United States v. Carter. Available from https://www.leagle.com/decision/ 
1998556159f3d3971502 (Accessed: 16.04.2018).

United States v. Schave (1999) 3d 839 - United States v. Karl C. Schave 990 F. Available from https://www.legal-tools.org (Accessed 16.04.2018).

United States v. Stephenson (1991) 928 F2d 728. https://www.ussc.gov/sites/default/files/pdf/training/onlinelearningcenter/supporting-materials/Revocation-of-Probation-and-Supervised-Released.pdf (Accessed 16.04.2018).

United States v. Stoural (1993) d 372 - United States v. 0 Stoural. Available from https://www.legal-tools.org/en/doc/c18557/ (Accessed 16.04.2018).

Williams v. Hunter (1957) 165 F. (2d) 924; 24 C.J.S., Criminal Law, § 1572. Available from https://www.atg.wa.gov/agoopinions/courts-deferred-imposition-sentence-crimes modification and-revocation-probation. (Accessed: 16.04.2018).

Wood H, Brown G (2014) Psychoanalytically-informed clinical supervision of staff in probation services. Psychoanal Psychother, 28:330-344.

Yıldız E, Tiryaki M (2015) Denetimli serbestlik sisteminde meslek elemanlarıınn eğitim ve iyileştirme sürecinde yaşadığı sorunlar ve çözüm yolları, In Türkiye'de Denetimli Serbestlik 10. YII Uluslararası Sempozyumu, Uluslararası Yaklaşımlar (Ed D Ozyoruk):1-7. Ankara, T.C. Ceza ve Tevkif Evleri Genel Müdürlüğü.

Zorlu AS (2014) Denetimli serbestlik uzmanlarının tükenmişlik düzeyleri (Yüksek lisans tezi). Hacettepe Üniversitesi, Ankara.

Yazarların Katkıları: Tüm yazarlar, her bir yazarın çalışmaya önemli bir bilimsel katkı sağladığııı ve makalenin hazırlanmasında veya gözden geçrilmesinde yardımc olduğunu kabul etmişlerdir.

Danışman Değerlendirmesi: Dış bağımsız

Çıkar Çatışması: Yazarlar çkar çatışması bildirmemiştir.

Finansal Destek:Yazarlar bu çalışma için finansal destek almadıklarını beyan etmişlerdir

Authors Contributions: All authors attest that each author has made an important scientific contribution to the study and has assisted with the drafting or revising of the manuscript.

Peer-review: Externally peer-reviewed.

Conflict of Interest: No conflict of interest was declared by the authors.

Financial Disclosure: The authors declared that this study has received no financial support. 